\title{
Teaching Writing for Non-Alphabetic Foreign Language during Covid-19: Lecturers' Point of View
}

\author{
Hamamah $^{1}$, Fariska Pujiyanti ${ }^{2}$, Ressi Maulidina Delijar ${ }^{3}$ \\ \{hamamah@ub.ac.id ${ }^{1}$, fariska_puji@ub.ac.id ${ }^{2}$, ressimd@ub.ac.id $\left.{ }^{3}\right\}$ \\ Universitas Brawijaya, Indonesia ${ }^{1,2,3}$
}

\begin{abstract}
The Covid-19 pandemic has led to the implementation of online learning. Online learning, which is currently being implemented, certainly cannot cover all the aspects needed, especially the lack of interaction and demonstrations. This causes lecturers to find difficulties in teaching writing classes, especially writing in non-alphabetic foreign languages for beginners. By using qualitative methods, this study describes the difficulties experienced by lecturers in teaching writing orthographic characters in the Covid-19 pandemic conditions. The participants involved were 24 lecturers from Chinese literature and Japanese literature from some universities in Indonesia, in which both languages have Hanzi and Kanji characters, respectively. The findings of this study are, the lecturers find it difficult to demonstrate online how to write characters that are in accordance with the strokes and stroke order, besides, lecturers also have difficulty finding applications or software that can be used for teaching writing orthographic characters. The lack of interaction on the video conference platform was also recognized by the lecturers as an obstacle because they could not check students' work in real time at the same time. The results of this study will be used to provide input to institutional management in order to create strategies and possible solutions that can help to overcome these problems.
\end{abstract}

Keywords: Chinese, Japanese, Orthographic Characters, Writing

\section{Introduction}

Covid-19 was firstly reported on December, 2019 in Wuhan, China, and it has affected several countries in an instant period. On 2nd March, 2020, Covid-19 affected Indonesia for the first time [1]. The number of infected and death case due to Covid-19 had increased significantly. The fast spread of Covid-19 caused WHO to announce the claim of Covid-19 as the global pandemic [2]. One of Covid-19's health regulations are lockdown announced by WHO to decrease the number of Covid-19's infection since it has been giving great impacts in several fields. Covid-19 clearly influences the learning process that the learning process is changed into online learning process. Its process requires students and lecturers to do the learning process on their own home without applying a face-to-face learning process. However, it is clearly not easy to fully change the learning process into online one.

An online learning process requires the use of technology. The technology has provided several applications to facilitate the online learning process. It means that lecturers also need to be able to use technology in doing online learning process. However, the use of technology becomes a great challenge in learning foreign language due to the lack of interaction and demonstration between lecturers and students, especially in teaching writing for Non-alphabetic foreign language. 
Previous research written by Hafidz [3] analyzed the dilemmatic of lecturers in applying online English learning during Covid-19 in rural area. It aimed to describe the students' motivation to learn English language skills during Covid-19. Meanwhile Destianingsih and Satria [4] studied the needs of the students of Polytechnic of Bengkalis to find the effective method for online English learning during Covid-19. The result shows that the effective method of online English learning is by using Zoom application, where students can make in an interaction through online live video. It requires teacher to be more creative in provoking students to be active in online learning process. Agung, Surtikanti and Quinones [5] conducted a research about the perception of the students of STKIP Pamane Talino toward online learning during Covid-19. The result showed that there are three major obstacles in online learning process, i.e., the internet connection, the accessibility of the teaching media and the compatibility of tools to access the media. It suggested the friendly platform to effectively facilitate students in doing online learning.

Those previous researches focused on the students' needs and motivation to facilitate teachers in applying online English learning process, while this research focuses on the lecturer's point of view. It analyzes the challenges faced by lecturers in teaching writing for non-alphabetical foreign language during Covid-19.

\section{Methods}

This research was a descriptive analytic research. Respondents involving were lecturers from Chinese literature and Japanese literature, in which both languages have Hanzi and Kanji characters, respectively. The number of respondents was 24 from Chinese Literature, Japanese Literature, Japanese Language Education, Japanese Language and Culture Study Programs from some universities in Indonesia. Data were taken mainly from questionnaire since this study tries to elicit and describe the difficulties experienced by lecturers in teaching writing orthographic characters in the Covid-19 pandemic conditions. The questionnaire about online learning modified from Napitupulu [6] was distributed online via Google Forms. The answers from the questionnaires then were classified and scrutinized to answer the research questions.

\section{Results and Discussion}

Before discussing the perceptions and challenges faced by Chinese and Japanese language lecturers, we first present the results of the survey. The survey is about what language courses are the most difficult to do online. The language course in the questionnaire refers to 4 language skills, namely writing, reading, speaking, and listening. The following are the results of a survey about language courses that are most difficult to do online. 


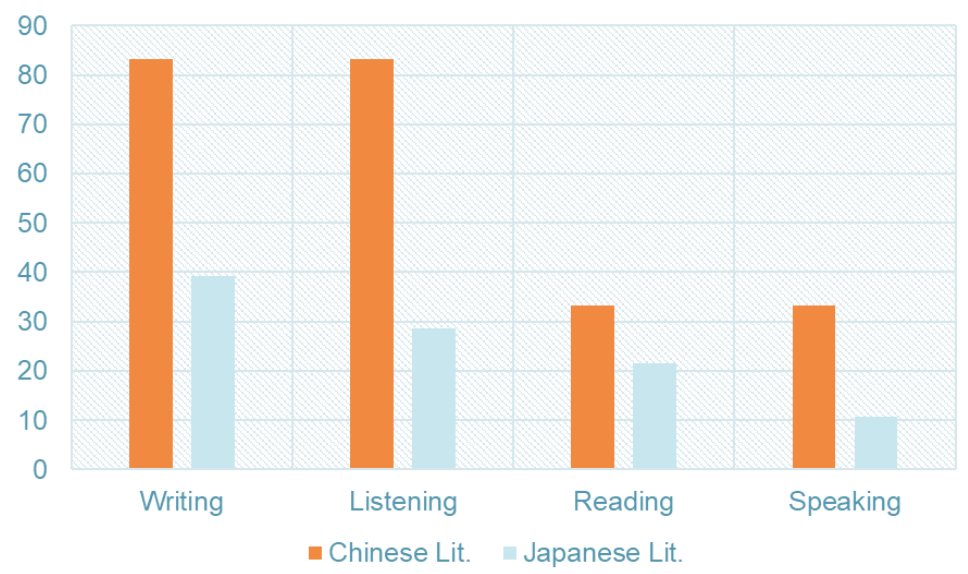

Fig. 1. Lecturers' Perception on Which Language Skills Course is The Hardest to be Taught Online during Covid-19.

From Figure 1, it can be seen that lecturers from Chinese literature consider language courses that are difficult to be taught online is writing course $(83.3 \%)$ and listening course $(83.3 \%)$. Meanwhile, $39.3 \%$ of Japanese literature lecturers agreed that the most difficult course to be done through media or online platforms is writing. If it is accumulated from both majors, Chinese literature and Japanese literature, it can be concluded that the participants feel that writing skills are the most difficult to be taught online. From these data, this study attempts to do further investigation to the challenges faced by lecturers from the two study programs when teaching online. However, the difficulties described in this study only focus on the difficulties faced in teaching writing.

\subsection{Challenges Faced by Japanese Literature Lecturers}

The researchers summarized some of the challenges faced by Japanese Literature lecturers by including their opinions about teaching writing online. These difficulties are as follows.

"The writing skill that becomes the problem is writing foreign letters. Even though there are websites or other online learning platforms that students usually use to learn independently, related to stroke order, sometimes the materials on the website, related to vocabulary are slightly different from the material taught in classroom, so I inevitably have to prepare the material independently to teach and this is time consuming" (Participant No. 20, Female, 28).

From the statements of the participants above, it can be seen that, the main problem in teaching writing skills is writing characters. Even though there are websites or other online learning platforms that can be used by students to learn independently related to stroke order, sometimes the materials on the website especially related to vocabulary are slightly different from the material taught by the lecturer, therefore the lecturer inevitably has to prepare the material and according to this participant, preparing material is time consuming.

"It is difficult to teach writing Kanji using online platform, because we cannot check students' works directly" (Participant No. 50, Female, 46). 
In online learning, lecturers cannot demonstrate how to write characters as in offline classroom using a blackboard and markers. Lecturers find it difficult to teach writing characters because they feel they do not have media that is similar to blackboards in offline classes. The difficulty of the lecturer in demonstrating how to write accurately also makes the lecturer feel worried about students' understanding.

"Because learning to write Japanese, in this case, Kanji, is very difficult to [do] online. [This is] because the accuracy of the stroke is also an important point" (Participant No. 61, Male, 32).

Related to the previous statement, this participant also emphasized the importance of demonstrating the right stroke orders. This is because characters in Japanese, or Kanji, are different from other foreign language characters such as English which use the alphabet. Accuracy of strokes in character writing is very important because in some cases, this will change the meaning of a character.

"In Basic Kanji Writing class, it is difficult to check how students write Kanji in the correct order unless the students use video conference" (Participant No.55, Female, 29).

Lecturers also faced challenges in providing online feedback. If in offline classes the lecturer can provide direct corrections, in online classes this is difficult to give feedback simultaneously. Interaction can only be done during a video conference or video call. However, another obstacle arises when not all students can do video conferencing (it could be due to their network errors, credit limitations, etc.).

'It takes effort to check students' writing one by one. In offline class, we can check students' work by having a discussion" (Participant No. 74, Female, 53).

In line with the previous statement, this participant also said the same thing regarding providing feedback. In offline classes, work can be checked together with students, but for online learning this cannot be done. As a result of seeing a computer screen too often, it affects eyes health.

"It is difficult to check if the students complete the assignments independently, especially in writing activities. Plagiarism is likely to happen" (Participant No. 73, Female, 49).

Apart from the difficulties for lecturers to check and provide feedback, lecturers also felt that they could not monitor students' understanding due to limited space and time. The lecturer also found students who did copy and paste in writing their works. This is slightly different from writing in an offline classroom which can be directly monitored. Students' work can also be ascertained without copying and pasting from the internet. 


\subsection{Challenges Faced by Chinese Literature Lecturers}

Like Japanese literature lecturers, Chinese literature lecturers also have difficulties during the teaching and learning process of online writing classes. The following are some of the opinions of participants from Chinese literature.

"At the moment I don't know a kind of software that helps the instructors to prepare the material, especially in writing Chinese characters. Actually, they can still download videos about how to write, but teachers cannot directly monitor the stroke process" (Participant No. 53, Male, 27).

First of all, Chinese literature lecturers find it difficult to prepare material for basic writing classes. Lecturers make use of instructional videos available on the internet about how to write Chinese characters (Hanzi), but this method is considered less sollutive because it is difficult to monitor students during the process of practicing writing characters online. Meanwhile, writing classes require a lot of practice and tests. Like Japanese Literature lecturers, Chinese Literature lecturers also explained the importance of checking the writing process including their stroke order because the correct Hanzi writing has a certain writing order, and strokes.

"At the moment, I still do not know [information] regarding the use of special applications or software to teach students how to write Chinese characters, because the existing platforms are not sufficiently easy to teach writing" (Participant No. 53, Male, 27).

Participants also admitted that the Covid-19 pandemic that occurred so quickly meant that lecturers did not know much about applications or software that made teaching writing at a basic level easier. Video conferencing platforms like ZOOM already have a virtual whiteboard feature so that lecturers can demonstrate how to write. However, writing using a trackpad or mouse is also not easy to do. The characters are written untidy and difficult to read.

"Practicing Hanzi writing directly using a virtual whiteboard available on a PC is a little difficult to do with a mouse. Using pen tablet is possible, but the price is quite expensive" (Participant No. 80, Female, 24).

The solution that has been done by the lecturer when teaching writing is to use a pen tablet. The use of this tool makes it easy for lecturers to demonstrate how to write Hanzi characters. However, another obstacle arises related to the price of the tool that is not affordable for temporary online classes.

\subsection{Live Interaction and Demonstration}

Looking back from the difficulties described in the previous section, it can be seen that in the teaching and learning process, writing for beginner classes require direct interaction and demonstration. Both languages, Japanese and Chinese, have their own characters that require special attention in their way of writing (the strokes, and the order).

Japanese characters have several elements, namely Bushu 部首, Kakusuu 画 数, and Hitsujun 筆順 [7]. In her research, Yulia [7] explains that Bushu is a stroke that forms a Kanji, 
while Kakusuu is the number of strokes in a character. In contrast to the two elements, Hitsujun, is a sequence of strokes in the writing of a Kanji.

Just like Kanji, Hanzi, which is the root of the Kanji character, also has writing rules of character. In writing Chinese characters, the terms 笔画 (bihua) and 笔顺 (bishun) are known.

笔画 (bihua) is the basic strokes that comprise Hanzi, while 笔顺 (bishun) is proper stroke order used to write Hanzi [8]. That way, Kanji and Hanzi have similarities in terms of standardized writing procedures, so that the correct writing of the two characters is according to the procedure.

Lack of direct interaction in online classes makes it difficult for lecturers to know whether students have applied the correct writing process or not. In fact, writing characters with the correct stroke order and procedure can help students to write characters correctly and more quickly [8]. Errors in strokes can also affect the accuracy of writing characters (Xiao in Zhang [9]). Therefore, the correct writing process can affect the character production.

Students who learn to write without knowing the basic knowledge of the procedures for writing characters will affect the quality of character production, and can even change the meaning of the characters written. Many characters in Japanese and Chinese look visually the same, for example in Chinese, 天 tiān 'sky' and 夫 fü 'husband' are similar in the shape but different in meaning, other examples are 末 mò and 未 wèi also 字 zì and 学 xué.

Providing students with stroke knowledge also helps them to use index-key based manual dictionaries. The Japanese manual dictionary uses Bushu while Chinese uses the radical index 部首. Without learning to write at the basic level properly, students may not be able to identify the parts or elements forming characters, which also results in difficulty accessing the manual dictionary.

\section{Conclusion}

Challenges from both majors in Teaching Writing for Non-Alphabetic Foreign Language during Covid-19 are: 1) choosing platforms and tools, 2) preparing teaching materials, 3) Giving online feedback, and 4) time limitations. For foreign languages, which have orthographic characters, learning to write the correct characters is very important because differences in strokes can affect the meaning contained in each character. Thus, interactions and demonstrations in the writing class deserve special attention. The results of this study can be used to provide input to institutional management in order to create strategies and possible solutions that can help to overcome these problems.

\section{Acknowledgements}

This research was funded by DPP/SPP Fakultas Ilmu Budaya, Universitas Brawijaya Tahun 2020 .

\section{References}

[1] Ihsanuddin, "Fakta Lengkap Kasus Pertama Virus Corona di Indonesia," Kompas.com, 2020. [Online]. Available: https://nasional.kompas.com/read/2020/03/03/06314981/fakta-lengkap- 
kasus-pertama-virus-corona-di-indonesia?page=all.

[2] BBC News, "Covid-19 pandemic: Tracking the global coronavirus outbreak," BBC News, 2020. [Online]. Available: https://www.bbc.com/news/world-51235105.

[3] M. Hafidz, "The Dilematic On-Line English Learning during the Covid-19 Pandemy in Rural Area," J. English Teaching, Appl. Linguist. Lit., vol. 3, no. 2, pp. 43-48.

[4] A. Destianingsih and A. Satria, "Investigating Students' Needs for Effective English Online Learning During Covid-19 for Polbeng Students," ELT-Lectura, vol. 7, no. 2, pp. 147-153, 2020.

[5] A. S. N. Agung, M. W. Surtikanti, and C. A. Quinones, "Students' Perception of Online Learning during COVID-19 Pandemic: A Case Study on the English Students of STKIP Pamane Talino," SOSHUM J. Sos. Dan Hum., vol. 10, no. 2, pp. 225-235, 2020.

[6] D. Napitupulu, "Kesiapan Implementasi Sistem E-Learning Di Lingkungan Universitas XYZ," in Seminar Nasional Technopreneurship dan Alih Teknologi, 2016, pp. 64-75.

[7] N. Yulia, "Students'mastery on Writing Kanji at Japanese Language Education Study Program of UNP," J. Kata Penelit. tentang Ilmu Bhs. dan Sastra, vol. 1, pp. 35-43, 2020.

[8] J. H. S. Ma, "Keys to Chinese Character Writing. Step-by-Step Directions to Writing Characters Quickly and Easily.," 2000.

[9] H. Zhang, "A review of stroke order in hanzi handwriting," Lang. Learn. High. Educ., vol. 4, no. 2, pp. 423-440, 2014. 